\title{
II. The Burden of Proof and other Procedural Devices in Tort Law
}

\author{
Ivo Giesen
}

\section{A. INTRODUCTION}

This contribution deals with the (importance of the) burden of proof, especially in tort cases, and its relationship with procedural law in general, i.e. other devices within procedural law, most notably evidence law. To be more precise: I will analyse the burden of proof in European tort law systems against the background of the use of other procedural devices that might be of importance for the substantive law outcome of specific (liability) cases. Meant are of course such devices as presumptions (be it in the form of "Anscheinsbeweis", "res ipsa loquitur" or otherwise) or the standard of proof ("Beweismaß"), but also procedural duties to supply information, and the like. To phrase my topic in more general terms: what is to be analysed here is the relationship between all these various (procedural) devices, including the burden of proof, when it comes to tort cases.

The way in which I propose to conduct this analysis is as follows. I will first describe, in general terms, what is generally meant in European legal systems with the burden of proof, and the possibility of a reversal of that burden. I will provide the reader with a description of this instrument, note its aim and function and focus on its place in tort law, especially with regard to the possibility of accepting a reversal of that burden. Next, I will follow the same path for three other devices that are rooted mostly in the law of civil procedure but do have great practical impact on substantive tort law solutions. These devices are the standard of proof, the use of factual presumptions and the use of duties to provide information to the opposing party. What is meant by those rather general notions will be explained hereafter. Having analysed these four instruments as such, I will focus on the relationship between them, mainly by analyzing their specific aims and functions within procedural (and possibly substantive) law. The GermanAustrian-Dutch concept of what I will call, for now, procedural duties to inform will be specifically promoted as a means to equal procedural chances without opening Pandora's box of additional tort claims (see below section F.).

It would be next to impossible to provide an in-depth account of all the European civil procedure and tort law systems on all these four instruments and 
the questions arising in that respect. Instead of embarking thus on a route to foreseeable failure, I have chosen to limit myself to the most important basic features and to select my sources, information and inspiration from several countries in a rather eclectical fashion, using Dutch, German, Austrian, French, Belgian and English legislation, case law and doctrinal works in various different combinations throughout the following sections of this contribution. ${ }^{1}$

\section{B. The Burden of Proof and its Reversal}

\section{An Ancient Concept Used Worldwide}

4 The (division of the) burden of proof is a legal institution or instrument that is usually embedded in the law of evidence, if dealt with explicitly at all in legislation. Usually it is captured in one single, rather general rule. That rule decides, basically, who is obliged to prove one or more factual elements ("facts in issue") of a certain type of claim. ${ }^{2}$ For example, who should prove the existence of wrongfulness in a tort claim? Or who should prove the existence of a contract? And so on. The general, worldwide accepted rule regarding the (division of the) burden of the proof is that each party to civil proceedings (both the claimant and the defendant) is required to prove those facts that form the minimally required factual content of the legal rule upon which the claim or defence is based. What requirements are in fact necessary depends then on the substantive private law rules invoked. If one does not succeed in proving these facts, and a so-called non liquet situation (i.e. a situation in which the facts that needed to be proven could not be proved) arises, the law will assume that, and proceed as if, the fact in question has not occurred. ${ }^{3}$ This general rule is leading everywhere and is considered self-evident. ${ }^{4}$

5 In France, a rule of this kind has been laid down in art. 1315 Code Civil (Cc) and in art. 9 Code de Procedure Civil (CPC), just as is the case in Belgium. ${ }^{5}$

\footnotetext{
${ }^{1}$ Instead of trying to incorporate all or even most of the vast and well documented doctrinal works (especially from the Germanic legal systems) on the topic of burden of proof and evidence, I have drawn extensively from my own comparative work in this regard, most notably from $I$. Giesen, Bewijs en aansprakelijkheid (2001), which contains references to the most important literature in Germany, France and England until 2000. Recent developments have been studied from more recent sources, of course. As a practical guide to several systems, see S. Leitner et al., Beweise und Beweisführungsgrundsätze im Zivilrecht (2008).

2 See P. Murphy, Murphy on Evidence (2007) 71.

3 See below at no. 10, and Giesen (fn. 1) 12 specifically on the non liquet situation.

${ }^{4}$ Cf. Giesen (fn. 1) 75 ff.; Chr. Heinrich, Zur Funktion der Beweislastnormen, in: Chr. Heinrich (ed.), Festschrift für Hans-Joachim Musielak (2004) 231 ff.; E. Schmidt, Die Beweislast in Zivilsachen - Funktionen und Verteilungsregeln, Juristische Schulung (JuS) 2003, 1008, speaks in this respect of a "Verlegenheitslösung" because "in real life" things might have happened completely differently instead. See also I. Giesen/T.F.E. Tjong Tjin Tai, Proportionele tendensen in het verbintenissenrecht (2008) $106 \mathrm{f}$.

${ }^{5} \mathrm{Cf}$. H. Geens, De verdeling van de bewijslast over de partijen in het verzekeringsrecht en het gemeen verbintenissenrecht, in: B. Allemeersch/P. Londers/S. Sroka (eds.), Bewijsrecht (2007) 161, dealing with Belgian law as laid down in art. 1315 Burgerlijk Wetboek (BW) and art. 870 Gerechtelijk Wetboek (GW).
} 
Under Dutch law, the Code of Civil Procedure contains a differently worded, but similar rule in art. 150 Wetboek van Burgerlijke rechtsvordering (Rv). English lawyers are not fond of deciding cases on the basis of the burden of proof. ${ }^{6}$ They know of no specific statutory provision in point, but do start the sometimes necessary judgments on the burden of proof from the same premise. ${ }^{7}$ In Germany, inclusion of a rule of this kind in $\S 193-198$ of the first draft of the Bürgerliches Gesetzbuch (BGB) was later deemed unnecessary (because it was considered self-evident), ${ }^{8}$ but the leading theory on burden of proof starts here as well. ${ }^{9}$ Austrian law does the same. ${ }^{10}$ The rule itself actually dates from Roman times, as evidenced in the classic saying "actori incumbit probatio, reus excipiendo fit actor" 11 and is also accepted in the modern ALI/ Unidroit Principles of Transnational Civil Procedure (in Principle 21.1). ${ }^{12}$

\section{Exceptions are Possible when Justified}

This general rule is not without exceptions. It is generally acknowledged everywhere that it is possible to come to a so-called reversal of the burden of proof under certain (strict or less strict) circumstances. Basically, this means that a party other than the party carrying the burden according to the normal rule explained above is indeed entrusted with the task of proving a certain element ${ }^{13}$ of a claim. That other party then also bears the consequences and risks of a possible failure to do so.

Without going too much into the details regarding such possible reversals of the burden of proof in several systems, ${ }^{14}$ it is important to analyse at least to some extent the possible reasons (better: justifications) for accepting such a shift. A valid reason for doing so needs to be present because the implications

6 Cf. Peter Pain J., in Clark v. MacLennan [1983] 1 All England Law Reports (All ER) 416, at 425: "It may seem that to base one's judgment on the burden of proof is the last resort of a judge who cannot make up his mind.".

7 E.g. Rhesa Shipping Co SA v. Edmunds (the Popi M) [1985] 2 All ER 712, at 718. See also Murphy (fn. 2) 75 .

8 Heinrich (fn. 4) 235; Schmidt, JuS 2003, 1009.

9 I am referring of course to the "Normentheorie" by L. Rosenberg, Die Beweislast auf der Grundlage des Bürgerlichen Gesetzbuchs und der Zivilprozessordnung (1965) as modified into the "modifizierte Normentheorie" by later theoretical accounts (cf. Heinrich (fn. 4) 231).

${ }^{10}$ W. Rechberger (ed.), Kommentar zur ZPO (2006) Vor $\$ 266$, no. 11.

11 On that Roman foundation, see K.-H. Schwab, Zur Abkehr moderner Beweislastlehren von der Normentheorie, in: W. Frisch (ed.), Festschrift für H.-J. Bruns (1978) 516 ff.

12 It reads: "Ordinarily, each party has the burden to prove all the material facts that are the basis of that party's case". On (an older version of) that Principle, see A. Kemelmajer de Carlucci, La charge de la preuve dans les Principes et Règles ALI/Unidroit relatifs à la procédure civile transnationale, Uniform Law Review (Unif. L. Rev.) 2001, 915 ff.

13 To be sure, a reversal could be accepted for instance for the element wrongfulness or the causation requirement, and so on. It is important to note each time which condition for tortious liability is at stake. Examples are offered by C. van Dam, European Tort Law (2006) $281 \mathrm{ff}$.

14 An example: the French art. 102 of Law no. 2002-203 of 4 March 2002 (Loi Kouchner) states, in short, that the defendant must prove that the Hepatitis $\mathrm{C}$ infection was not due to a blood transfusion. On that article, see Cass. Civ. 1re, 14 June 2007, Juris-Classeur Periodique (JCP) éd. G. 2007, IV, 2481, and A. Vignon-Barrault/Ph. Casson, Chronique de responsabilité civile, Petites Affiches 2008, 13 ff. 
of a shift in the burden of proof are quite serious and not to be taken lightly. Reversing the burden indeed equals the shift of the risks of not being able to prove a certain fact onto someone else. The consequence could be that the other party in fact loses the case whereas he would not have lost if the normal division had been retained. Or, in opposite terms: shifting the burden of proof may result in winning a case that would otherwise have been lost due to evidential difficulties.

8 The rationale put forward to justify a reversal of the burden of proof usually consists of one or more of several arguments. One is that it is meant to improve the protection and the position of the victim of a certain act (the plaintiff). It does so in particular if the application of the general rule regarding the apportionment of the burden of proof would put that victim in unreasonable difficulties due to, for instance, the technical or organizational complexity of the defendant's activities and, as a result, making the facts difficult to prove. Other reasons used are the idea that he who benefits from a certain activity should also bear the extra burdens related to that activity (profit theory), the idea of channelling liability in a certain direction, the idea of promoting the preventive effects of (a harsher form of) liability, the need to protect fundamental rights at stake, the wish to decrease the dependence of one party, the need to decrease the imbalance in information between the litigants, the existence of insurance coverage, or to serve the goal of being able to invoke a substantive rule despite evidential difficulties. ${ }^{15}$ That last argument was put to the forefront forcefully by Lord Hope of Craighead when he stated in Chester v. Afshar:

"The function of the law is to enable rights to be vindicated and to provide remedies when duties have been breached. Unless this is done the duty is a hollow one, stripped of all practical force and devoid of all content." 16

9 In general, even if not made explicit, for a reversal of the burden of proof legal policy and normative considerations (and not just factual arguments, which vary depending on the case ${ }^{17}$ ) are decisive. As far as I am concerned, this is indeed how it should be; normative points of view, and not mere factual particulars, should govern the apportionment of the burden of proof and thus also the reversal of the burden of proof, if indeed accepted. My reason for following this line of reasoning is that the reversal of the burden of proof leads to a much tighter or stricter tort (liability) law regime and such a tightening must be justified on normative grounds, just as would be needed for a change in substantive tort law.

15 More generally on the possible reasons for a reversal, Giesen (fn. 1) 409-421 and $447 \mathrm{ff}$.

16 See Chester v. Afshar [2004] 4 All ER 587; [2005] 1 Appeal Cases (A.C.) 134, 162 f. In that case, his Lordship used this reasoning to reach a "narrow modification" of traditional causation principles. The same principle is put forward in $\operatorname{Van} \operatorname{Dam}(\mathrm{fn} .13)$ 286, and as the leading argument for a reversal of the burden of proof in Giesen (fn. 1) 449-451.

17 Giesen (fn. 1) 443 f., and 410 ff. for an overview of the normative arguments. In the same vein N. Jansen, Principles of European Tort Law? Rabels Zeitschrift (RabelsZ) 70 (2006) 767. For criteria see also Schmidt, JuS 2003, 1010. 


\section{Aim and Function}

Since facts cannot always be ascertained with the required amount of certainty (see also section C.) each and every legal system needs a rule that decides what happens if that situation (a non liquet) in fact arises. Such a rule is a rule on the burden (and risk) of proof. Its aim and function is thus to actually decide a case in instances of persisting factual uncertainty, in case of indecisiveness. It does so by providing the answer to the question: who runs the risk of losing if uncertainty remains? ${ }^{18}$ The answer is, as stated before, that if no or too little evidence was delivered, the judge will decide as if the fact in question is non-existent.

\section{Its Place in Tort Law}

Tort law as part of private law occupies as such no special place in this regard. What has been said before basically applies equally to tort law as to contract law, family law, and commercial law and so on. The one exception to this might be that tort law (or somewhat broader: liability law) seems to provide us with a fair (and maybe even large) share of exceptions to the fundamental rule. This is not that strange if one considers that (potentially) wrongful acts are being litigated on rather often, while many tortious acts depend on proof which is hard to come by. The litigants were usually strangers to each other before the possible tort was committed. There were thus no prior dealings, no previous contracts, files, etc., to fall back on. Tortious acts are usually also "split second wrongdoings" in the sense of events happening all of a sudden and within a very limited period of time, with no person paying explicit attention to what is or rather was happening, making useful witness statements rare or not really reliable. Thus, many tort claims are packed with evidential difficulties, and in many cases these difficulties are of a structural character, i.e. they come up in each tort case of the same kind. All tort law systems are thus confronted on a regular basis with cases in which plaintiffs seem to be in need of some "evidential" assistance. If indeed the system (be it the legislator or the court) decides to provide that aid, a reversal of the burden of proof is a serious candidate. Indeed, it would be an obvious one. Be that as it may, it is certainly not the only one.

\section{The Standard of Proof}

\section{Definition of a Well-Known Concept ${ }^{19}$}

The standard of proof refers to the extent or degree of certainty or probability that the evidence delivered by the litigants must generate in the mind of the judge when deciding an issue of fact. ${ }^{20}$ If the so required degree is reached, the court can say it is convinced of the "truth" (whatever that may be in a more philosophical sense) of a certain factual proposition and decide the case ac-

${ }^{18}$ Cf. Murphy (fn. 2) 71 f.; Schmidt, JuS 2003, 1008, and Heinrich (fn. 4) 233 and 241. For Austria, see Rechberger (fn. 10) Vor $\$ 266$, no. 8.

19 See also M. Brinkmann, Das Beweismaß im Zivilprozess aus rechtsvergleichender Sicht (2005).

${ }^{20}$ Cf. Murphy (fn. 2) 101. 
cordingly. Included in the foregoing description is the notion that in principal, but with exceptions, the courts in Europe are free to attach their own weight to different pieces of evidence. Whether they believe an eyewitness or not, to give one example, is at their discretion. Related to that notion is the starting point that the standard of proof is decided according to the weight that the judge in question decides to give the evidence; it is thus in principal a subjective judgement, one which is objectified however by the obligation for a judge to motivate his decision. ${ }^{21}$

13 As to the degree or extent of evidence required to pass the standard of proof hurdle, it would seem that common law and civil law countries are divided. ${ }^{22}$ In England ${ }^{23}$ proof "on the balance of probabilities" (is it more likely than not?) would suffice, while elsewhere the measure to reach is put (somewhat) higher, for instance at "a reasonable degree of certainty" in the Netherlands or "at a practical degree of probability or certainty that silences doubt without totally excluding it" as it is specified in Germany, which is an even higher standard, laid down in § 286 Zivilprozessordnung (ZPO) and usually described as "sehr hohe Wahrscheinlichkeit". ${ }^{24}$ In Austria the required degree is that of "die hohe Wahrscheinlichkeit". This is based on $\S 272$ österreichische Zivilprozessordnung (öZPO) and case law. ${ }^{25}$

14 Noteworthy is also that in most systems the standard of proof can vary according to the type of case that is being dealt with. Most prominently is of course the difference made in England between the standard of proof in civil cases as opposed to criminal cases. ${ }^{26}$ In Germany, for instance, the degree of certainty can and sometimes is lowered in certain (private law) cases when "Glaubhaftmachung", i.e. "überwiegende Wahrscheinlichkeit", seems to suffice. ${ }^{27}$ In line with that, Dutch courts lower the standard in so-called "kort geding" procedures (very fast proceedings, issued at short notice, before a single judge, based mainly on oral arguments) to "aannemelijkheid" or: is it probable? ${ }^{28}$

${ }^{21}$ For details, see Giesen (fn. 1) 49 f., 53-55.

22 See for instance E.L. Sherwin/K.M.A. Clermont, Comparative View of Standards of Proof, American Journal of Comparative Law (AJCL) 2002, $243 \mathrm{ff}$. The ALI/Unidroit Principles of Transnational Civil Procedure try to bridge the gap by stating in Principle 21.2: "Facts are considered proven when the court is reasonably convinced of their truth." (emphasis added, $I G$ ). See further on this "divide" and on this Principle: M. Brinkmann, The Synthesis of Common and Civil Law Standard of Proof Formulae in the ALI/Unidroit Principles of Transnational Civil Procedure, Unif. L. Rev. 2004, 875 ff.

${ }^{23}$ Murphy (fn. 2) 107. See also (in German) Chr. Schröder, Das Beweisrecht im englischen Zivilverfahren (2007) $222 \mathrm{ff}$.

24 See Giesen (fn. 1) 50 and 55; H.-J. Musielak, Grundkurs ZPO (2007) 281, and BGH 17 February 1970, Entscheidungen des Bundesgerichtshofs in Zivilsachen (BGHZ) 53, 245, 256 (Anastasia-Urteil). For Belgium, a degree of "redelijke zekerheid" suffices, see B. Allemeersch, Taakverdeling in het burgerlijk proces (2007) 466.

25 See the discussion (and further references) in C. Bumberger, Zum Kausalitätsbeweis im Haftpflichtrecht (2003) 45 ff., 49 and 182, and OGH 9 July 2002, Juristische Blätter (JB1) 2003, 249 f.; OGH 17 November 2004, JB1 2005, 464.

${ }^{26}$ See Murphy (fn. 2) 101.

${ }_{27}$ Musielak (fn. 24) 283.

${ }^{28}$ Cf. Giesen (fn. 1) 56 f. 


\section{Aim and Function}

The principle aim of the standard of proof is to have a certain measure, to be applied equally to all litigants in the same sorts of cases, to decide whether the burden of proof has been discharged. In order to perform that function, the degree of evidence required can as such vary without much trouble. To do so would be feasible if in a given situation demanding more evidence to be supplied would be unjustified. For possible reasons why demanding more might be unjustified, one can fall back on the justification for having a reversal of the burden of proof as exemplified earlier. ${ }^{29}$

The standard of proof, however determined and set will be of influence on the burden of proof. If a court is convinced of the existence of a certain fact, the required evidence apparently has been brought forward, allowing the judge to decide the matter accordingly. The risks associated with the burden of proof are then no longer at stake since a non liquet situation will not arise. From this it follows that if the required standard were to be lowered, the degree of evidence needed to reach the standard would also be lower, making it less likely that the burden of proof will be decisive for that case at hand. Lowering the standard is thus equal to less cases being decided on the burden of proof. ${ }^{30}$

\section{Its Place in Tort Law}

When it comes to the standard of proof, a tort case will in principal not be treated differently from any other private law case. The standard of proof is set at a certain level in each legal system and for some cases a lower standard is accepted, as explained above. The most important deviation from this, however, is that in Germany the lowering of the standard of proof that is laid down in $\S 287$ ZPO is especially relevant for and functional in liability cases. That article provides that both the existence of damage and the amount thereof can be assessed and determined (or even estimated) by using (only) an "erhebliche Wahrscheinlichkeit". Equally important is that the question of remoteness of damage, the so-called "haftungsausfüllende Kausalität" in German terminology, is supposed to be dealt with according to this (lowered) standard of proof. Its purpose is to (try and) avoid a non liquet. ${ }^{31} \mathrm{~A}$ similar possibility to estimate the amount of damage suffered is provided for in the Dutch Civil Code, in art. 6:97 Burgerlijk Wetboek (BW).

${ }^{29}$ See above at no. 8, and Giesen (fn. 1) 475 and $477 \mathrm{f}$.

${ }^{30}$ Cf. Bumberger (fn. 25) 42.

${ }^{31}$ On all this, see for instance G. Baumgärtel, Beweislastpraxis im Privatrecht (1996) no. 377 ff., and recently BGH 20 March 2008, Monatsschrift für Deutsches Recht (MDR) 2008, 799 on the use of $\S 287$ ZPO. The same deviation from the regular standard applies, according to $\S 252$ $\mathrm{BGB}$, for the determination of lost profits. 


\section{Presumptions of Fact}

\section{General Thoughts on Presumptions}

18 Once again it will not be possible to cover the topic of (factual) presumptions in all its finesses and richness in this contribution. The theme is just too diverse and broad for that. What is possible however is to sketch a few general lines of thought, thought to be common to most legal systems. The first is that a presumption is in essence a mode of reasoning which leads to certain inferences being drawn, i.e. to the acceptance of certain facts or legal consequences from other, proven facts. ${ }^{32}$ To do so, use is made of rules of thumb and facts that are common knowledge. A presumption thus provides the judge with the opportunity to base the existence of a certain factual element on the presence of another fact which has been proven. So, in essence, the object of proof (the fact that needs to be proven) is changed.

19 It is important to note, secondly, that accepting such a presumption does not change the burden of proof. It only denotes that for the time being that burden has been discharged. It is then for the opposite side to come forward with evidence to rebut that provisional judgment. In order to do so, the presumption must be countered to such an extent that the judge remains in doubt again as to the existence of the fact in question; going further and actually providing proof to the contrary is not needed. So, in essence, only the "evidential" burden of proof shifts when a presumption is accepted, but not the "legal" burden. ${ }^{33}$

20 A third aspect to mention is that both in England on the one hand as well as in Germany and Austria on the other hand, separate doctrines regarding the use of presumptions of fact have emerged. In England the notion of "res ipsa loquitur" (i.e. the case speaks for itself) and in Germany and Austria the doctrine of "Anscheinsbeweis" have arisen and (at least in Germany) gained enormous practical importance. ${ }^{34}$ Since both are (almost) confined to liability cases, I will deal with them below (section D.3). ${ }^{35}$

\section{Aim and Function}

21 As stated, a presumption does not alter the division of the burden of proof. It just makes it easier to come up with the proof needed because an additional way of "gathering" evidence is used, next to the usual modes of providing evidence. The function a presumption thus fulfils is that it might alleviate the evidential needs one may encounter (it is a "Beweiserleichterung") and that it provides for the possibility to use probabilities when deciding a case. Taking it one step further, one can also say that a presumption prevents the non liquet

${ }^{32}$ Cf. Giesen (fn. 1) 65; See also on presumptions W.D.H. Asser, Bewijslastverdeling (2004) $87 \mathrm{ff}$.

33 Giesen (fn. 1) 65 f.

${ }^{34}$ Cf. especially Baumgärtel (fn. 31) no. 227.

35 I will not deal with the doctrine of "Indizienbeweis" since doing so would not add a lot to the line of argument developed in this contribution. For more information, see Baumgärtel (fn. 31) no. 272 ff.; Rechberger (fn. 10) Vor $§ 266$, no. 21. 
situation from arising in certain instances; a presumption thus also prevents the (legal) burden of proof from becoming decisive. ${ }^{36}$

\section{Presumptions in Tort Law: Res Ipsa Loquitur and Anscheinsbeweis}

At the risk of sounding repetitious, it must be stressed once again that on a principal level the use of presumptions is not confined to or treated in any special way within tort law. Factual presumptions can and may be used also in contract cases, labour law, family disputes, etc. Be that as it may, (again) it does seem noteworthy that presumptions are in fact used relatively often in liability cases, although I have no empirical evidence at my disposal to back that proposition up with hard figures. The proposition does seem valid however given the extensive use that is made of, for instance, "Anscheinsbeweis" in Germany in liability cases (see below). The large numbers of cases that are decided in the Netherlands on the basis of the so-called "omkeringsregel" (a presumption of fact as to the existence of the condicio sine qua non requirement, which in fact started out as a genuine reversal of the burden of proof ${ }^{37}$ ) strengthen that educated guess on my part.

As mentioned, in England the notion of "res ipsa loquitur" and in Germany and Austria the doctrine of "Anscheinsbeweis" have become important, especially for tort cases. Without it being necessary to deal with these procedural instruments extensively, it should be noted that the English doctrine of res ipsa loquitur basically stands for the notion that sometimes the judge may infer negligence from the circumstances of the event that led to the injury because the injury is of the type that would not have occurred without negligence on someone's part. Usually pedestrians do not get struck by falling barrels of flour plummeting from a second floor storage facility. ${ }^{38}$ Of course this places res ipsa loquitur right within the law of negligence; it is designed, so to speak, for tort cases, allowing a court to draw an inference of a breach of a duty of care and thus allowing presumptions to flourish in that part of the law. The use of

36 Giesen (fn. 1) 65.

37 As regards causation, this specific rule gained momentum in the Netherlands a few years ago. The rule basically states that whenever a wrongful act creates or increases a certain risk of damage and that specific risk actually materializes, the causal link has been established, unless the wrongdoer can prove that taking preventive measures would not have prevented the damage from occurring. This so-called "omkeringsregel" was first used in the mid 1970s in cases of traffic accidents and accidents at workplaces, and was widened in its scope of application in the Dicky Trading II-case of Hoge Raad (HR) 26 January 1996, Nederlandse Jurisprudentie (NJ) 1996, 607. See also W.H. van Boom/I. Giesen, The Netherlands, in: B. Winiger et al. (eds.), Digest of European Tort Law. Vol. 1. Essential Cases on Natural Causation (2007) 102-11, 215 f. and $408 \mathrm{f}$. By now, it is widely held that the ambit of this rule is reduced so considerably that it will apply only (again) if traffic rules or specific safety rules are breached, cf. I. Giesen, De aantrekkingskracht van Lorelei, in: T. Hartlief/S.D. Lindenbergh, Tien pennenstreken over personenschade (2009) $69 \mathrm{ff}$.

38 I am referring here of course to the famous case of Byrne v. Boadle 159 English Reports (Eng. Rep.) 299 (Exch. 1863). For more information on this principle or rule or maxim, see recently G. Gregg Webb, The Law of Falling Objects: Byrne v. Boadle and the Birth of Res Ipsa Loquitur, Stanford Law Review (Stan. L. Rev.) 59 (2007) 1065 ff.; Giesen (fn. 1) 69 ff. (also dealing with French law in this respect). 
res ipsa loquitur has also been questioned, and forcefully at that, however, due to its difficulties in determining its application. ${ }^{39}$

24 In Germany and Austria the doctrine of "Anscheinsbeweis" fulfils a similar, yet in practice more important function. It supplies liability law with a detailed (albeit complex) possibility of using presumptions to decide cases that present factual difficulties. "Anscheinsbeweis" relates to the fact that if a certain injury has occurred, at first glance ("am ersten Anschein") a certain cause is likely to be present as well and responsible for the event. This inference is based on general rules of experience. ${ }^{40}$ Again I will not dwell on the preconditions for its use nor its consequences, let alone all the legal questions that still remain as regards this doctrine. Here it suffices to mention that "Anscheinsbeweis" does not lead to a reversal of the burden of proof, that rebutting the presumption suffices, without having to provide proof to the contrary and that it is typically used to prove either causation and/or negligence. ${ }^{41}$ Of course, that specific area of application also denotes its special importance for liability questions.

\section{E. The Duty TO PROVIDE INFORMATION (SEKundëre Behauptungslast)}

\section{Several Forms of Information Duties}

25 Under modern rules of civil procedure litigants are increasingly obliged to provide information to their opponents and/or the judge, even if they are unwilling to do so. There are an increasing number of instruments available that stimulate the fact-finding process. The importance of such - in general terms "duties to provide information" is that the more information comes out in the open, the more facts can be ascertained or at least be subject to discussion in the litigation process. ${ }^{42}$ Such a duty to provide information is achieved through the use of several types of rules pertaining to the transfer of knowledge.

26 Even though this paper is not the appropriate forum to provide a more or less exhaustive overview of rules in several legal systems in Europe in this regard, a few instances can be mentioned. ${ }^{43}$ Such an instance is the French general

39 See for example Chr. Witting, Res Ipsa Loquitur: Some Last Words? Law Quarterly Review (LQR) 117 (2001) $392 \mathrm{ff}$.

40 To give one fairly recent example: breaking of a piece of a tooth when biting a piece of meat is not considered, according to rules of experience, to be typically due to the presence of some foreign object hidden in the dish, which means that "Anscheinsbeweis" cannot be invoked. See BGH 5 April 2006, Neue Juristische Wochenschrift (NJW) 2006, 2262.

${ }^{41}$ From the vast amount of literature on this topic I will only mention J. Metz, Der Anscheinsbeweis im Straßenverkehrsrecht, NJW 2008, 2806 ff.; C. Jungmann, Der „Anscheinsbeweis ohne ersten Anschein“, Zeitschrift für Zivilprozess (ZZP) 120 (2007) 459 ff.; Baumgärtel (fn. 31) no. 227 ff.; Rechberger (fn. 10) Vor § 266, no. 22; Bumberger (fn. 25) 51 ff., all with further references.

42 Giesen (fn. 1) $18 \mathrm{f}$.

43 For more information on the following, see Giesen (fn. 1) 18-38, with further references. 
duty to contribute to finding the truth (art. $10 \mathrm{CPC}$ ) and the more specific duty to introduce certain pieces of evidence into the proceedings if ordered to do so (art. $11 \mathrm{sec}$. 2 CPC). Similar in vein are the Dutch duty to provide relevant facts completely and truthfully (art. $21 \mathrm{Rv}$ ) and the power given to a judge to demand further elaboration on or about certain pleadings (art. $22 \mathrm{Rv}$ ). Mention can also be made of the duty to substantiate factual elements by having to name the expected defences the opposing party will invoke and by having to name what type of evidence is available (art. $111 \mathrm{sec} .3$ and $128 \mathrm{sec} .5 \mathrm{Rv}$ ). The English Civil Procedure Rules (CPR) have vested the judge with the power to order parties to supply him with information (Rule 18.1 CPR), coupled with a statement of truth as regards the information so provided (Rule 22.1 (1) CPR). The rules on disclosure also contribute to the presence of information (Rule 31 CPR). According to German procedural law, information can be obtained by using the duty contained in $\S 138 \mathrm{ZPO}$, which states that parties need to make sure that their declarations are truthful and complete. Under $\S 139$ the judge is obliged to make sure that the parties elaborate on the facts of the case, and name their means of evidence. ${ }^{44}$

A general duty to supply the opponent spontaneously with all the relevant facts of a case is in principal not accepted in the European systems of civil procedure, ${ }^{45}$ but specific duties to provide the judge and/or the opposing party with information are accepted, and rightly so. The ALI/Unidroit Principles of Transnational Civil Procedure further exemplify this. ${ }^{46}$ These duties need sanctioning of course, for instance by using, as in Germany, the "Präklusion”, ( $\$ 296$ sec. II ZPO) but that is another (difficult, and usually not easy to achieve) topic altogether.

\section{One Specific Example Highlighted: Sekundäre Behauptungslast}

One specific example of an information duty that deserves more of our attention is the (in German) "sekundäre Behauptungslast" or (in Dutch) "aanvullende stelplicht" or "gemotiveerde betwisting", which could also be named (even though it is non-existent in English law) the "the duty to provide an extra motivated pleading". This instrument is part of the law of evidence and warrants our attention because of its relevance for tort cases and its potential to solve the evidential needs of (usually) plaintiffs. What we are dealing with here is the obligation of one litigant, usually the defendant, to not only deny the plaintiff's statement of claim and the facts asserted therein, but to go one step further and to extra underpin and motivate that denial by bringing in factual details and relevant sources. It comes down to this: the defendant is charged by the case law with a duty to substantiate his defence or claim that he has not

44 For German law in this respect, see also I. Saenger, Grundfragen und aktuelle Probleme des Beweisrechts aus deutscher Sicht, ZZP 121 (2008) 142-144.

45 For German law for instance Baumgärtel (fn. 31) no. 305 ff.

46 Principle 21.3 states: "When it appears that a party has possession or control of relevant evidence that it declines without justification to produce, the court may draw adverse inferences with respect to the issue for which the evidence is probative." It is based on the notion of good faith (Principle 11.1). 
acted wrongfully, for instance. He has to do so by supplying information on all the factual aspects of the claim. What is thus needed is that the defendant takes an extra step when denying the asserted facts by supplying a certain degree of extra information (which is typically not available to the plaintiff).$^{47}$ Think of a doctor who is obliged to hand over his medical file, with his notes, to the patient claiming damages. Since a breach of the medical standard of care is usually hard to prove for a patient, the courts tend to "lower" the burden of proof a bit, give it a different content, when duties of care are supposedly breached.

29 By using this instrument the substantiation of a claim is thus put partly upon the defendant. This is done however without reversing the (legal) burden of proof, which is of course important. ${ }^{48}$ Only the (evidential) burden of producing (pieces of) evidence is shifted. ${ }^{49}$ If the defendant complies with this duty, the plaintiff is still obliged to prove, using the extra information provided, his claim. What happens if in fact the duty is not complied with, is that the existence of the fact at stake is considered to be given (on the basis of $\S 138$ Abs. III ZPO in Germany and art. $149 \mathrm{Rv}$ in the Netherlands). ${ }^{50}$ In Austria, the foregoing is dealt with somewhat differently however. Here it seems to depend on the type of case whether a reversal of the burden of proof is accepted as the sanctioning mechanism or not. ${ }^{51}$ Its legal basis can be found in $\S 184$ öZPO. ${ }^{52}$

30 In Germany this legal notion, based on the notion of "Treu und Glauben", can be invoked if three conditions have been met. First, the party which carries the burden of invoking and stating facts to support its claim has no further knowledge concerning the determining facts because that party has been outside of the realm in which the facts in question occurred, while second, the opposing litigant knows or is supposed to know these facts, and, thirdly, it can be attributed to that opposing party to be obliged to introduce those facts into the dispute at hand.$^{53}$ In Austria the same conditions generally apply. ${ }^{54}$ In the Netherlands case law has not come up with a specific (similar) list of conditions to be met, but in essence the same principles do seem to apply there as well. ${ }^{55}$

47 See Giesen (fn. 1) 39 ff.; Baumgärtel (fn. 31) no. 307 f., 347 ff., as well as the following footnotes.

48 See D. Magnus, Beweislast und Kausalität bei ärztlichen Behandlungsfehlern, ZZP 120 (2007) 353.

${ }^{49}$ On these two notions, see Baumgärtel (fn. 31) no. 9, 14; Murphy (fn. 2) 71 f.; Giesen (fn. 1) 12 f., with ref. in fn. 60 .

${ }^{50}$ Cf. Saenger, ZZP 121 (2008) 145; Giesen (fn. 1) 41 and 43-47, although the range of possible sanctions is, wrongly as far as I am concerned, considered to be somewhat wider in the Netherlands, see HR 15 December 2006, NJ 2007, 203 (NoordNederlands Effektenkantoor/Mourik).

51 J. Rassi, Die Aufklärungs- und Mitwirkungspflichten der nicht beweisbelasteten Partei im Zivilprozess aus österreichischer Sicht, ZZP 121 (2008) 176-178, who claims that a reversal of the burden of proof should not be used (ibid., at 199).

52 Rassi, ZZP 121 (2008) $187 \mathrm{ff}$.

53 See, for example BGH 18 May 1999, NJW 1999, 2887 f.; Saenger, ZZP 121 (2008) 144; Magnus, ZZP 120 (2007) 353; Giesen (fn. 1) 41. Cf. also Baumgärtel (fn. 31) no. 307.

54 See Rassi, ZZP 121 (2008) 176.

55 Giesen (fn. 1) 42. 
Examples of the use of this "sekundäre Behauptungslast" can be found in German law in the area of labour law, in maintenance law, in company law and in competition law (i.e. misleading advertising, which is closely connected to tort law). The German Bundesgerichtshof (BGH) has used the concept in medical negligence cases recently as well. ${ }^{56}$ It has done the same in relation to a lawyer who is being sued for a failure to warn his client and in respect of tax advisors. ${ }^{57}$ In Austria the instrument is currently being used in (parts of) competition law, transportation law and bankruptcy law. ${ }^{58}$ In the Netherlands liability claims against medical practitioners, notaries, and presumably also lawyers, can be dealt with along these lines, just as several labour law issues, while it has also been used in intellectual property law in the past. ${ }^{59}$

\section{Aim and Function of the Sekundäre Behauptungslast}

This "sekundäre Behauptungslast" is meant and used as an instrument to alleviate the plaintiff's burden of proof in cases in which it is obvious that such burden cannot be met without some external help being offered. The burden of proof is not shifted onto the defendant but lessened in the sense that one is given certain factual information that is needed to build one's claim and which was not available before. An important question is of course why someone would be obliged to help out his opponent this way. Isn't litigation like a battle or even worse still, a "war"?

Basically this duty is accepted, as far as I am concerned, because without the duty to supply information the burden of proof would become too burdensome. Since it would be an illusion to think that the plaintiff could provide the evidence needed without this duty bestowed on the opponent, the protection substantive law aims to offer a party would become illusionary as well. ${ }^{60}$ And that is something we do not wish to accept. In the end, it is thus the desire to safeguard the protection offered by substantive law that ignites this procedural protective measure. Of course that is a course of action taken more often, due to the close ties that exist between the law of evidence and substantive law in terms of achieving certain aims or outcomes. ${ }^{61}$

${ }^{56}$ See BGH 14 June 2005, NJW 2005, 2614; Saenger, ZZP 121 (2008) 144, and Magnus, ZZP 120 (2007) 353 and fn. 28, with references and critical comments as regards the use in medical negligence cases.

57 BGH 26 June 2008, Der Betrieb (DB) 2008, 1738, 1740 and BGH 4 June 1996, DB 1996, $1869 \mathrm{f}$.

${ }^{58}$ Rassi, ZZP 121 (2008) $176 \mathrm{f}$.

59 Giesen (fn. 1) 39 f. Especially in medical liability cases, this is standing case law since HR 20 November 1987, NJ 1988, 500 (Timmer/Deutman). See also HR 18 February 1994, NJ 1994, 368 (Schepers/De Bruijn); HR 13 January 1997, NJ 1997, 175 (De Heel/Korver); HR 7 September 2001, NJ 2001, 615 (Anesthesie); HR 23 November 2001, NJ 2002, 386 (Ingenhut) and HR 15 December 2006, NJ 2007, 203 (NoordNederlands Effektenkantoor/Mourik).

${ }^{60}$ See the advice to the Supreme Court by Asser in the case of HR 10 January 1997, NJ 1999, 286 (Notaris W.), at no. 2.9, and Giesen (fn. 1) 42.

${ }^{61}$ Cf. Giesen (fn. 1) 43 and 465-467 in more general terms. 


\section{Information Duties and Tort Law}

34 The above mentioned information duties can be accepted, basically, for any type of judicial dispute, and are thus not confined to issues of tort law. Neither are tort disputes excluded from these basic duties. In essence, these rules thus can govern "our" tort cases just as they could cover a contract case or a dispute over the ownership of a piece of land. Tort law is, yet again, not special in this regard, but there are certain types of tort claims that benefit greatly from the existence of this concept.

35 In principle, the same goes for the specific case of the "sekundäre Behauptungslast". Its use and applicability is not confined, in principle, to certain cases, although its use has not yet become "universal". Of course the conditions that need to be met in order to be able to use the instrument do in fact shape the extent to which it can be invoked in practice. This duty has however already proven to be useful in liability cases, most notably, at least in the Netherlands, in cases of medical negligence and other forms of professional negligence. ${ }^{62}$ The information deficit a patient usually encounters when suing a medical practitioner can be balanced by imposing on the doctor the duty to come forward with certain information at his disposal, thus levelling the "playing field" between both parties to some extent. Cases of misleading advertising also come to mind as types of cases in which the concept can be useful. To my mind the usefulness of this concept has however not been fully grasped everywhere ${ }^{63}$ and where it has, the extent of its potential use has not been fully appreciated, or so it would seem.

\section{F. Further Analysis: The Relationship between the Procedural Devices}

\section{Similar Aims and Functions}

36 What we have seen so far is that in most legal systems, in one way or another, legal tools or instruments are being developed to escape the regular outcomes and consequences of rules of evidence, such as the fundamental rule designed to divide the burden of proof between the litigants. Deviating from the regular application of one or more of the above mentioned instruments of the law of evidence is usually accepted when it serves a specific purpose, i.e. most notably, arranging for a reduction in evidential burdens of whatever sort, sometimes also called a "Beweiserleichterung bis hin zur Beweislastumkehr" 64 for

62 To be sure, in the Netherlands such cases are either rooted in contract law or in tort law, without this distinction being relevant for the duty of care.

${ }^{63}$ Belgian law does not seem to accept this way of reasoning, at least not without further qualifications, see M.E. Storme, Algemene beginselen van bewijs in het vermogensrecht, in: B. Allemeersch/P. Londers/S. Sroka (eds.), Bewijsrecht (2007) 11. However, Allemeersch (fn. 24) $126 \mathrm{f}$., does seem to accept a similar duty (with reference to Dutch case law in this regard).

${ }^{64}$ On that concept and the possible confusion it entails, see W. Laumen, Die „Beweiserleichterung bis hin zur Beweislastumkehr“ - Ein beweisrechtliches Phänomen, NJW 2002, 3739 ff. 
the plaintiff. This deviation from normal standards is deemed justified because the plaintiff can invoke one or more valid (substantive and normative) arguments for a change in his unfavourable position, for instance because profit theory or the dependence of the plaintiff in his relationship with the defendant dictates so. ${ }^{65}$

Each instrument (be it a reversal of the burden of proof, a lowering of the standard of proof, and so on) functions as a legal route that can be used in order to achieve a desired result. This desire is fuelled, usually, by the fact that we are trying to cope the best we can with a situation of what I would call structural evidential difficulties, i.e. we are dealing with types of cases that (almost) always run into the same or similar difficulties as regards the possibilities of proving certain elements of the case. To give only one example: requiring proof that a patient would have chosen an alternative treatment or no treatment at all if he had known and been informed in time about the medical risks of the treatment actually provided is bound to lead to a causation requirement that is as good as impossible to prove in any case of that type. ${ }^{66}$

The concept of informational duties as explained above is, to use that as an example, suited, at least in principle, to tackle the problem at hand if that problem is indeed one of "evidential needs". ${ }^{67}$ This is true for problems of proof as regards the unlawfulness but also when dealing with condicio sine qua non issues. ${ }^{68}$ Building a case to actually be allowed by a judge to use this form of "evidential alleviation" is manageable in practice since it is considered possible to use the same arguments one would use for defending a reversal of the burden of proof. ${ }^{69}$ Another option might of course be to lower the demands usually imposed on a litigant to reach the required standard of proof. One can be more or less strict in what is required. ${ }^{70}$ Instead of asking for a reasonable degree of certainty (for instance a "redelijke mate van zekerheid") a judge might be satisfied if the proof delivered reaches the standard of more probable than not (i.e. the usual standard in England) or something similar ("aannemelijkheid" for instance).

Both these examples lead to a situation in which the evidential difficulties for a plaintiff are lessened, at least to a certain extent. That is not to say however, that the defendant will thus automatically lose his case. This depends on the instrument used and the consequences attached to that specific devise. These consequences need not be all too harsh (considering the defendant's position) in all cases, it depends on the instrument chosen.

65 On these and several other arguments (in essence these arguments are usually of a normative character), see Giesen (fn. 1) $409 \mathrm{ff}$. and no. 8 f. above.

${ }_{66}$ More on this in Giesen (fn. 1) 455-458.

${ }^{67}$ Giesen (fn. 1) 39 ff.; Asser (fn. 32) 115 ff.

${ }^{68}$ Cf. HR 23 November 2001, NJ 2002, 386 (Ingenhut).

${ }^{69}$ Giesen (fn. 1) 475.

${ }^{70}$ Cf. for Belgium for instance I. Boone, Het "verlies van een kans" bij onzeker causaal verband, Rechtskundig Weekblad (R.W.) 2004, 96. 


\section{But Different Consequences}

40 Of course, not all of the analysed instruments to alleviate or change the position of the plaintiff have the same or similar legal consequences. This means that the choice for one of them instead of another is not without significance. For example, using the "sekundäre Behauptungslast" and concluding that this obligation has not been lived up to leads in principle to the conclusion that the fact in dispute must be considered to be true, thus excluding the need for any further evidence. On the other hand, a reversal of the burden of proof relocates that burden to the other litigant, allowing evidence to be delivered while a presumption presupposes that the proof has been delivered, for the time being at least, but allowing counter-evidence to be handed down.

\section{Caveat: Substantive Law Could also Be Used}

41 So far I have dealt with several procedural instruments designed or at least used to circumvent unwanted substantive outcomes. It is important to note that one does not have to fall back on these procedural devices in order to achieve a desired result. Substantive law can also provide a "remedy" for forms of structural evidential difficulties. For instance, if a legislator (or, exceptionally a court) introduces or accepts a form of strict(er) liability instead of the regular rules on fault liability, this is usually done by excluding the elements (or: conditions for acceptance of liability) of wrongfulness and/or (subjective) fault. Excluding such an element of course means that proof in that regard is no longer needed. ${ }^{71}$

42 If and when proof of the condicio sine qua non connection between the act complained of and the damage suffered is hard or impossible to prove, a solution might be to change the way one interprets that (causal) element of the claim. By extending the interpretation given to a certain condition for liability it may become easier to prove the existence thereof. What used to be a problem of proof may then have disappeared. ${ }^{72}$ This method seems to have been used in England not that long ago. ${ }^{73}$ This method of course has the advantage that the non liquet situation will be avoided completely, which in turns means that the division of the burden of proof will not be decisive..$^{74}$ A rather paramount disadvantage would of course be that the liability system as such is "invaded" or impaired in the sense that one of the major conditions for liability is downplayed to a large extent or re-formulated.

43 The same disadvantage can be mentioned as one of the key factors when another substantive law solution is brought to the floor: proportional liability, or,

71 As a method to circumvent evidentiary difficulties strict liability is a much used instrument, cf. Giesen (fn. 1) 473, with further references.

${ }^{72}$ Giesen (fn. 1) 473 f., with further references.

73 In Fairchild v. Glenhaven Funeral Services Ltd. [2003] 1 A.C. 32, a case that dealt with using a more "flexible" test for causation when dealing with an asbestos claim and more possible defendants. On that case, for instance, K. Oliphant, England and Wales, in: H. Koziol/B.C. Steininger (eds.), European Tort Law 2002 (2003) 144 ff.; J. Stapleton, Lords a'leaping evidentiary gaps, Torts Law Journal 10 (2002) $276 \mathrm{ff}$.

74 Giesen (fn. 1) 475. Cf. also Bumberger (fn. 25) 92 ff. 
phrased in general terms, liability in conformity with and to the extent of the likelihood that a certain causal factor for which the defendant is responsible was indeed the cause of the damage suffered by the claimant. However, this solution has many advantages as well. Since this contribution cannot deal with this highly debated issue extensively, ${ }^{75}$ I will not dwell on this any further but only mention it as an alternative to a re-definition of the burden of proof as regards causation. ${ }^{76}$

The fact that both substantive and procedural solutions are indeed available to litigants begs the question as to the relationship between these two possible solutions to the same problem. Are these routes to choose from mutually exclusive, for instance? As the principal starting point I would say that if and when more than one instrument is (possibly) applicable, the claimant should be given the freedom to set his own course and decide for himself which variation to choose and use. The more instruments that are available, the better it is for a claimant since he can then choose the instrument that suits his needs best. Excluding some of the options if others are or can be of use would not sit well with the notion of private autonomy in private law matters, especially if the possible reasons and justifications for the concurring options are related or even the same.

\section{Concluding Remarks: Proportionality should be Leading when Choosing a Solution}

All these procedural and substantive options then raise one final question: how to choose from the options that are available? Does the claimant enjoy total freedom in this respect? If not, what guides the choice to be made and to what extent? In this respect it is of the utmost importance to remember that, at least as far as I am concerned, in civil procedure law - just as in substantive (contract) law - the opposing parties are bound, at least to a certain extent, by the notion of and rules deriving from (English) "good faith and fair dealing", (German) "Treu und Glauben", (Dutch) "redelijkheid en billijkheid", or any other terminology used for the same idea. ${ }^{77}$ To some extent, ${ }^{78}$ according to this notion, one must take account of the interest of the opposite side, even when you are involved in litigation with that other person. Suing someone does not

75 Which of course has been accepted in the Principles of European Tort Law, see Principles art. 3:103, 3:105 and 3:106, and the comments by J. Spier (ed.), Unification of Tort Law: Causation (Chapter 3), in: European Group on Tort Law, Principles of European Tort Law (2005) $46 \mathrm{f}$., 48 and 57.

${ }^{76}$ See in greater detail: Giesen/Tjong Tjin Tai (fn. 4) $100 \mathrm{ff}$, and especially $106 \mathrm{f}$. On (different variations of) proportional liability, see also G. Wagner, Gutachten zum 66. Deutschen Juristentag (2006) 59-61; Boone, R.W. 2004, 92; Th. Kadner Graziano, Loss of a Chance in European Private law, European Review of Private Law (ERPL) 2008, 1022.

${ }^{77}$ See most notably J.B.M. Vranken, Rechtsvergelijkende gezichtspunten bij de herziening van het civiele procesrecht in eerste aanleg, in: W.D.H. Asser/J.B.M. Vranken, Verantwoordelijk procederen (1999) 78-82, especially 80. In the ALI/Unidroit Principles of Transnational Civil Procedure, Principle 11.1 ("The parties and their lawyers must conduct themselves in good faith in dealing with the court and other parties.") accepts this notion as well.

78 The question as to what extent would open up a whole new discussion, of course. Given the time and space limitations, I have decided not to try to answer that question here. 
lead to a declaration of a mutual state of war and/or lawlessness. Even when in battle, certain rules need to be upheld and good faith decides on what (social) norms are indeed valid even when involved in litigation.

46 Given that starting point, the determination as to what instrument should or can be used to alleviate one party's evidential burden cannot be left totally to the freedom of the party able to initiate the course of action to take. Some control (by the courts) is needed and can be exercised. So, when deciding on what instrument to invoke to achieve a better position, any alleviation of the plaintiff's burden must be one that also takes into account the opposing side's interests, as far as reasonably possible. Hence, the choice to be made is for the solution that is proportionate to the goal aimed at. ${ }^{79}$

47 Such a proportional fashion of dealing with the evidential difficulties certain tort cases lead to and which need a solution that deviates from what the regular rules on burden of proof provide for ${ }^{80}$ could be the (more extensive) use of the aforementioned procedural duties to inform (see section E. above), specifically the "sekundäre Behauptungslast". These duties might - and do, as far as I can tell - provide an efficient means to level, if not equal, the procedural chances between the litigants in the proceedings without at the same time opening Pandora's box in the sense of allowing a vast amount of added, new and/or frivolous tort claims to pop up.

48 If this duty were to be accepted on a more general scale in European (tort law) systems, this would mean that one party, usually the defendant, would be obliged to provide certain information, thereby allowing the opposing party (usually the plaintiff) to use that information to strengthen its own case or at least to make it easier to provide the proof demanded for. It would do so without going so far as to completely reverse the chances of both parties as the typical reversal of the burden of proof would entail. Hence, the possible fear for opening floodgates to frivolous claims can be put to rest.

49 The foregoing is especially the case if the party obliged to provide information actually supplies this when asked to, because in that case the burden of proof will not be altered or even touched upon. The defendant supplies information, and helps out the plaintiff who would then still bear the risks associated with a non liquet situation. Only if the defendant would refuse or not be able, although obliged, to supply extra information or would not be able to completely fulfil the obligation to supply that extra information, would a sanction follow. This sanction could either be a reversal of the burden of proof or alternatively the acceptance of the fact in question as undisputed (and thus no longer needed as proof). Such a sanction might be relatively harsh, since it would lead to los-

${ }^{79}$ A certain level of proportionality is becoming more and more accepted in substantive liability law, for instance through the use of the loss of a chance theory. On that, see Giesen/Tjong Tjin Tai (fn. 4), and Kadner Graziano, ERPL 2008, 1009 ff.

${ }^{80}$ Whether such a deviation from the standard way of dividing the burden of proof is needed and justified is a different question altogether, and one which I will not try to answer here. For some thoughts on that, see section B.2, no. 6 ff. above. 
ing on the merits of the case or a reversal of the risks associated with the non liquet situation. But this sanction is then justifiable given the defendant's nonfulfilment of the procedural duty in question.

Given the different results that will ensue if either the information duty was met or was not met, the foregoing can and will only function properly (and proportionally) if and when the courts can find the proper way to decide on how much additional information they can and should ask from litigants. This aspect is of the utmost importance and the highest courts in Europe should keep lower courts' decisions under rather close scrutiny in this respect. ${ }^{81}$ If the amount of information the courts require becomes too high, the proportionality of the use of this instrument will soon be lost. Such a delicate balancing task corresponds however exactly with what we ask our courts to do on a daily basis in several other types of cases. We may therefore safely assume that our courts are up for this task.

${ }^{81}$ In the Dutch system, the decision on how much information should be supplied is one which rests with the lower court but the Dutch Supreme Court can and will rule on the soundness of the motivation given by the lower court, see Giesen (fn. 1) 40, with ref. in fn. 163. 